\title{
Autoimmune Regulator
}

National Cancer Institute

\section{Source}

National Cancer Institute. Autoimmune Regulator. NCI Thesaurus. Code C114321.

Autoimmune regulator ( $545 \mathrm{aa}, \sim 58 \mathrm{kDa}$ ) is encoded by the human AIRE gene. This protein is involved in both the activation of gene transcription and the inhibition of autoimmunity. 